Revisión bibliográfica

Volumen 31(3):835-844. Septiembre-diciembre, 2020

e-ISSN 2215-3608, doi:10.15517/am.v31i3.40655

http://www.revistas.ucr.ac.cr/index.php/agromeso

\title{
Métodos de identificación del virus de la fruta rugosa marrón del tomate (ToBRFV) en México ${ }^{1}$
}

\section{Identification methods for Tomato brown rugose fruit virus (ToBRFV) in México}

\author{
Luis Ismael Nolasco-García², Juan Luis Marín-León ${ }^{3}$,Jorge Eric Ruiz-Nieto², Jesús Hernández-Ruíz*
}

1 Recepción: 17 de febrero, 2020. Aceptación: 27 de mayo, 2020. Este trabajo formó parte de la tesis del primer autor para optar al grado en la Maestría en Protección Vegetal de Hortalizas de la Universidad de Guanajuato, México.

2 Universidad de Guanajuato, División de Ciencias de la Vida. Km 9 carretera Irapuato-Silao, Ex Hacienda. El Copal, Irapuato, Guanajuato. México.li.nolascogarcia@ugto.mx (https://orcid.org/0000-0003-3138-840X); jorge.ruiz@ugto.mx (https://orcid.org/0000-0002-3293-8066); hernandez.jesus@ugto.mx (*autor para correspondencia; http://orcid.org/0000-0002-6312-7506).

3 Comité Estatal de Sanidad Vegeta de Guanajuato, Av. Siglo XXI No. 1156, Predio Los Sauces C.P. 36547, Irapuato, Guanajuato, México. jlmarin13@hotmail.com (https://orcid.org/0000-0002-3693-6316).

\section{Resumen}

Introducción. El virus de la fruta rugosa marrón del tomate (ToBRFV) se reportó por primera vez en Israel y Jordania en 2014, causa daños en cultivos de jitomate en agricultura protegida. Objetivo. Recopilar información de la distribución conocida, situación actual y métodos de detección del ToBRFV. Desarrollo. Entre 2018 y 2019 se confirmó la presencia del virus en México, Estados Unidos, China, Alemania, Turquía, Reino Unido e Italia. Para la detección del virus se ha empleado microscopía electrónica y pruebas serológicas, pero estas no pueden diferenciar el ToBRFV de otros tobamovirus, la técnica de diagnóstico más eficaz para la detección son oligonucleótidos específicos desarrollados a partir de los aislados de Israel y Jordania. Los protocolos de higiene son el paso más importante en la prevención de las infecciones. Conclusión. Los esfuerzos para controlar el ToBRFV se centran actualmente en el uso de estrictas prácticas de sanidad y detección en semilla y planta, mediante técnicas moleculares de reacción en cadena de polimerasa con transcriptasa inversa (RT-PCR) con oligonucleótidos específicos, para evitar falsos positivos.

Palabras clave: tobamovirus, PCR, Solanum lycopersicum.

\begin{abstract}
Introduction. The tomato brown rugose fruit virus (ToBRFV) was first reported in Israel and Jordan in 2014, causing damage to tomato crops in protected agriculture. Objective. To collect information on the known distribution, current situation, and detection methods of ToBRFV. Development. Between 2018 and 2019, the presence of the virus was confirmed in Mexico, the United States, China, Germany, Turkey, the United Kingdom, and Italy. Electron microscopy and serological tests have been used to detect the virus, but these cannot differentiate ToBRFV among other tobamoviruses. The most effective diagnostic technique for detection is specific oligonucleotides developed from the isolates from Israel and Jordan. Hygiene protocols are the most important step in preventing infections.
\end{abstract}


Conclusion. Efforts to control ToBRFV are currently focused on the use of strict sanitation and detection practices in seed and plant, using molecular reverse transcriptase polymerase chain reaction (RT-PCR) techniques with specific oligonucleotides, which avoid false positives.

Keywords: tobamoviruses, PCR, Solanum lycopersicum.

\section{Introducción}

En el cultivo de tomate, las enfermedades virales son notoriamente difíciles de controlar, dado la aparición continua de nuevas cepas de virus existentes o virus nuevos. Los virus tienen un gran potencial para evolucionar y adaptarse rápidamente bajo presión de selección natural, debido a su gran tamaño de población y cuasiespecies que facilitan la variación genética y tiempos de generación cortos, generando falta de mecanismos de lectura de pruebas para los genomas (virus de ARN) (Hanssen et al., 2010).

Tobamovirus es el género más grande de la familia Virgaviridae, consta de 37 especies asignadas y seis subtipos del virus de mosaico de tabaco (TMV) como la especie tipo (Adams et al., 2009). Son virus vegetales rígidos en forma de bastón que se transmiten fácilmente a las plantas sanas por inoculación mecánica, semilla contaminada y contacto entre plantas, son excepcionalmente estables, sobreviven años en restos de plantas en el suelo y durante semanas o meses en estructuras de invernadero, macetas y herramientas hortícolas. Persisten en ropa y, lo más importante, en manos de los trabajadores. No se conoce un insecto vector para estos virus (Christie y Edwardson, 1994).

En Israel en el año 2014 y en Jordania en el año 2015, se reportó un nuevo tobamovirus denominado virus rugoso del tomate (ToBRFV), el cual ocasiona una reducción en la cantidad de flores, frutos, necrosis en el pedúnculo del fruto y mosaicos en hojas (Figura 1). En frutos de plantas enfermas se observan áreas de color amarillo o marrón y rugosidad en su superficie (Salem et al., 2016).

Posterior a la detección del virus de la fruta rugosa marrón del tomate (ToBRFV) en Israel y Jordania, la presencia de este virus se reportó en julio de 2018 en Westphalia, Alemania (Menzel et al., 2019), y Baja California, México (Camacho-Beltrán et al., 2019), en septiembre de 2018 en California, Estados Unidos (Ling et al., 2019) y en Michoacán, México (Cambrón-Crisantos et al., 2018); y en octubre de 2018 en Sicilia, Italia (Panno et al., 2019). Para el año de 2019 se reportó en Antalya, Turquía (Fidan et al., 2019); Shandong, China (Yan et al., 2019) y en sur de Inglaterra (Skelton et al., 2019).

En México, no se cuenta con evidencia técnico-científica que refiera pérdidas económicas y umbrales de infección del virus de la fruta rugosa marrón del tomate (ToBRFV) en los cultivos hospedantes, los cuales pertenecen a la familia Solanaceae, por lo que puede repercutir en la producción de estas especies vegetales a nivel nacional e internacional. El desconocimiento de esta nueva amenaza, así como la especulación en torno a este problema, tendrán un impacto en los costos de producción de los cultivos susceptibles a ser infectados por el virus (García y Bocanegra, 2018).

El objetivo de esta revisión bibliográfica fue recopilar información de la distribución conocida, situación actual y métodos de detección del virus de la fruta rugosa marrón del tomate (ToBRFV).

\section{Clasificación de los Tobamovirus}

La familia taxonómica Virgaviridae fue recientemente descrita, y agrupa virus cuya partícula viral posee forma de bastón (Latín Virga). Incluye los géneros Furovirus (cinco especies), Hordeivirus (cuatro especies), Pecluvirus 


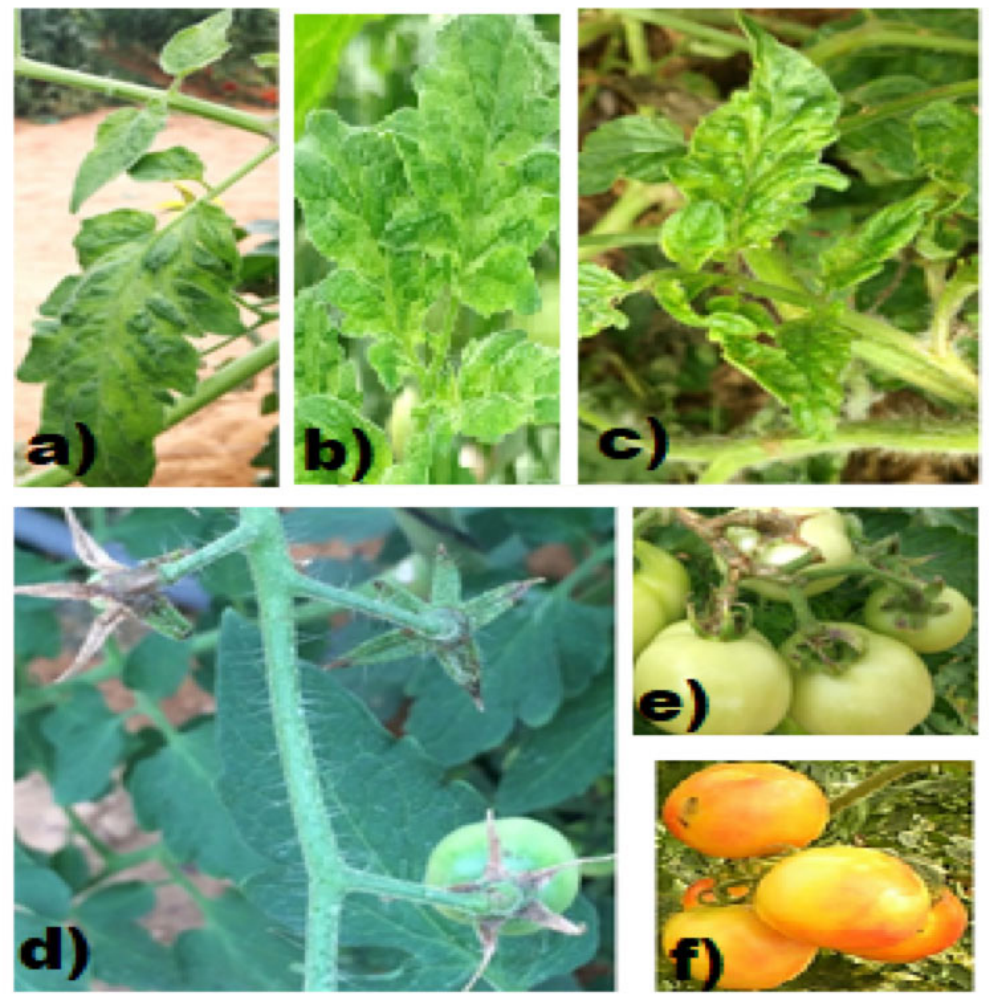

Figura 1. Virus de la fruta rugosa marrón del tomate (ToBRFV): a, b, c) patrón de mosaico sintomático en hojas de plantas de tomate; d) pedúnculos y cálices secos; e) síntomas necróticos en pedículo, cálices y pecíolos; f) frutos con manchas amarillas (Adaptado de Luria et al., 2017).

Figure 1. Tomato brown rugose fruit virus (ToBRFV): a, b, c) symptomatic mosaic pattern in tomato plant leaves; d) peduncles and dry chalices; e) necrotic symptoms in pedicles, calyces, and petioles; f) fruits with yellow spots (Adapted from Luria et al., 2017).

(dos especies), Pomovirus (cuatro especies), Tobamovirus (veinticinco especies) y Tobravirus (tres especies). Las características del grupo son, entre otras, proteínas de replicación de tipo alfa, genoma de ARN de sentido positivo con un motivo de ARN de transferencia asociado a su extremo 3' terminal, forma de bastón de sus viriones y un canal central de 20 a $25 \mathrm{~nm}$ de diámetro. Además, las proteínas de cápside poseen tamaños que oscilan entre 19 a $24 \mathrm{kDa}$ (Adams et al., 2009). En la Figura 2 se pueden visualizar las diferencias en los genomas de los virus pertenecientes a la familia Virgaviridae.

Las especies del género Tobamovirus son partículas en forma de varilla rígida, poseen un genoma de ARN monocatenario de sentido positivo de $\sim 6,4 \mathrm{~kb}$ con cuatro marcos de lectura abierto (ORFs por sus siglas en inglés de Open reading frames) (Dawson, 1992; van-Regenmortel et al., 2000). El ORF1 y ORF2 están separados por un codón de paro y codifican dos proteínas relacionadas con la replicación del virus con un peso de 126 y 183 kDa, respectivamente. El ORF3 codifica la proteína de movimiento de $30 \mathrm{kDa}$, mientras que el ORF4 codifica para la cápside de 17,5 kDa (Luria et al., 2017).

Los Tobamovirus se transmiten fácilmente de forma mecánica y semilla (partículas infecciosas en la testa), las cuales al germinar infectan las plántulas. El virus puede permanecer durante varios meses en residuos vegetales 


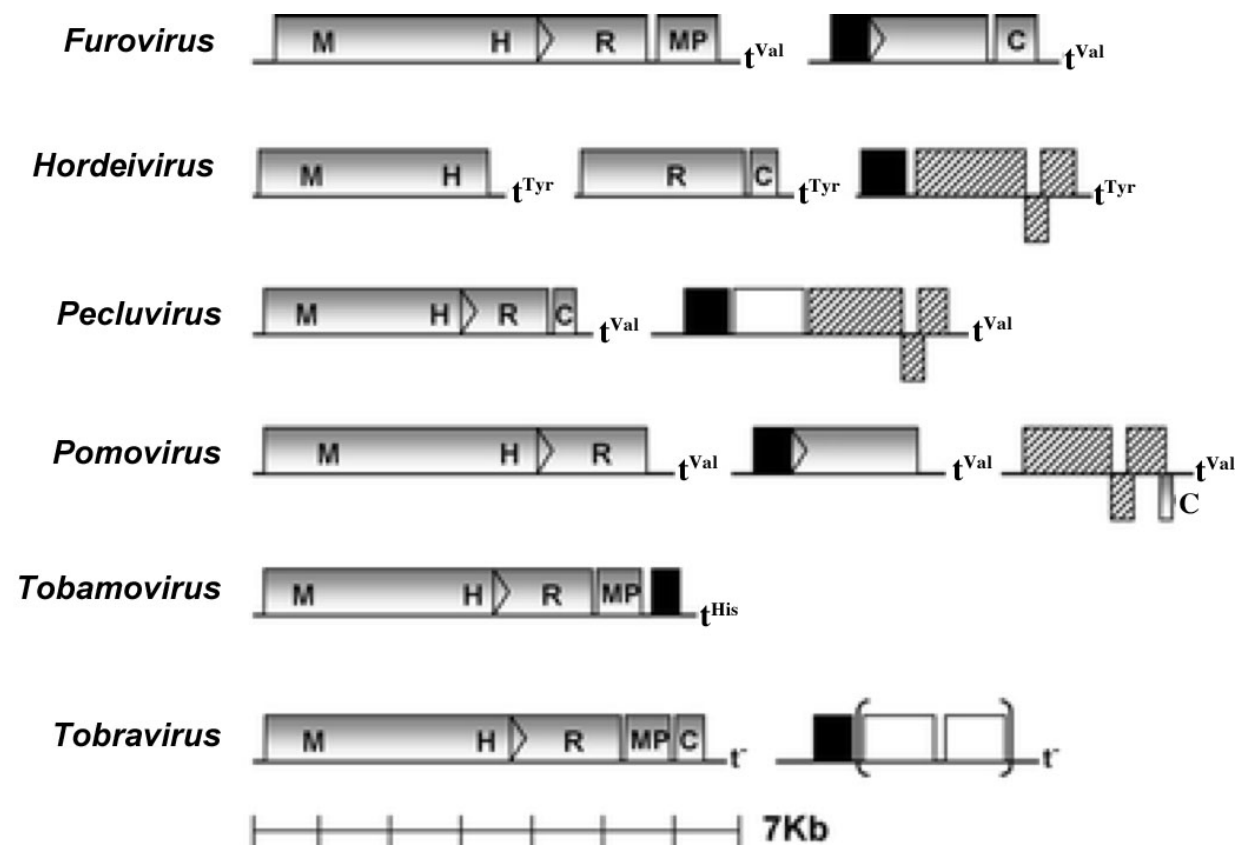

Figura 2. Diagrama representativo de los seis géneros de la familia Virgaviridae. Metiltransferasa (M), Helicasa (H) y ARN polimerasa dependiente de ARN (R). Las proteínas de triple bloque genético (TGB) están sombreadas, y las proteínas de la cubierta están en negro (Adams et al., 2009).

Figure 2. Representative diagram of the six Virgaviridae family genera. Methyltransferase (M), Helicase (H), and RNA-dependent RNA polymerase (R). Triple gene block proteins (TGB) are cross-hatched, and coat proteins are in black (Adams et al., 2009).

Cuadro 1. Principales especies del género Tobamovirus que afectan solanáceas.

Table 1. Main species of the Tobamovirus genus that affect Solanaceae.

\begin{tabular}{ccc}
\hline Especie & Nombre del virus & Abreviación \\
\hline Bell pepper mottle virus & Virus de moteado del pimiento & BPMV \\
Pepper mild mottle virus & Virus moteado suave del pimiento & PMMoV \\
Tobacco mild green mosaic virus & Mosaico verde atenuado del tabaco & TMGMV \\
Tobacco mosaic virus & Virus del mosaico del tabaco & TMV \\
Tomato brown rugose fruit virus & virus de la fruta rugosa marrón del tomate & ToBRFV \\
Tomato mosaic virus & Virus del mosaico del tomate & ToMV \\
Tomato mottle mosaic virus & Virus del mosaico moteado del tomate & ToMMV \\
\hline
\end{tabular}

y suelos contaminados con virus, y durante varios años en semillas infectadas (Dombrovsky y Smith, 2017). En el Cuadro 1 se presentan las principales especies de virus del género Tobamovirus que causan enfermedades en solanáceas. 


\section{Primer reporte y propagación en el mundo}

Entre octubre y noviembre del año 2014, en la aldea de Ohad al sur de Israel, se reportaron plantas sintomáticas con un patrón de mosaico en las hojas acompañadas de enchinamientos (amarillas, pequeñas y encorvadas hacia arriba) y fruta manchada. Los estudios epidemiológicos mostraron la propagación de la enfermedad en varias áreas en el sur y hacia las partes sureste y norte del país. En muestras recogidas de cultivares comerciales en todo Israel, se detectó un solo virus causante de la enfermedad. La secuencia completa del genoma del nuevo tobamovirus israelí mostró una alta identidad de secuencia al aislado jordano del virus rugoso del tomate (Luria et al., 2017).

En abril del año 2015, se detectó cultivo de tomate producido en invernadero en Jordania con presencia de síntomas leves de manchado mosaico foliar, pero fuertes síntomas de rugosidad color marrón en los frutos que afectaron el valor del cultivo. La incidencia de la enfermedad fue cercana al $100 \%$. El tipo de síntomas y el patrón de distribución de la enfermedad en los campos afectados sugirieron una etiología viral (Salem et al., 2016). Para comprobar este hecho se realizaron pruebas de RT-PCR contra los virus más comunes que infectan tomate, y que de acuerdo con Dovas et al. (2004) son: el virus del mosaico del pepino (PepMV), virus del tomate torrado (ToTV), virus de la patata (PVY), virus del mosaico de la alfalfa (AMV) y virus del bronceado del tomate (TSWV).

El nuevo virus de Jordania mostró un evento de recombinación entre las bases 534 y 848; la madre menor podría ser potencialmente ToMMV, y el mayor de los padres la cepa de "Ohio V" de TMV. Un árbol filogenético derivado de secuencias dentro del segmento de nt 534 a 848 mostró que el tobamovirus de Jordania provenía de una rama junto con ToMV y ToMMV aislados, contrario al árbol filogenético derivado del resto del genoma (Salem et al., 2016).

En septiembre del año 2018, se observó un brote de una enfermedad que presentaba mosaicos, moteados y retraso del crecimiento de las plantas de tomate injertado en un invernadero del sur de California, Estados Unidos. La detección inicial de una muestra sintomática fue positiva para el virus del mosaico del pepino (PepMV) y el virus del mosaico del tomate (ToMV). Se diseñó y validó un nuevo conjunto de cebadores específicos para ToBRFV con el fin de evitar una reacción cruzada con ToMV y ToMMV; este conjunto de cebadores fue: ToBRFV-F (5503), 5' -GAAGTCCCGATGTCTGTAAGG-3' y ToBRFV-R (6344), 5'-GTGCCTACGGATGTGTATGA-3', un producto de PCR esperado ( $842 \mathrm{pb}$ ). Con los cuales una búsqueda BLASTn de la base de datos NCBI, reveló una identidad de secuencia del 99,6 \% con otros dos aislados del ToBRFV de Jordania (Salem et al., 2016) e Israel (Luria et al., 2017).

En Alemania, en julio del año 2018, se observaron síntomas inusuales en frutos y hojas en más de 25 ha de invernaderos que cultivaban tomate en la región del Bajo Rin de Renania del Norte-Westfalia. Los síntomas en hojas presentaban clorosis, mosaicos con protuberancias de color verde oscuro, frutos con manchas amarillas, a menudo concentradas alrededor del cáliz. Para la identificación del patógeno se empleó un par de cebadores (514 Tobamos 1: 5'-GGGAATCAGTTTCAAACRCA-3' ;515 Tobamoas1: 5'-GGGGGGATTCGAACCYCT-3') diseñados para detección universal de los tobamovirus, los cuales resultaron en ampliaciones del tamaño esperado (560 pb) para todas las muestras sintomáticas. Los productos de PCR revelaron $100 \%$ de identidad de nucleótidos (números de acceso de GenBank: KX619418 y KT383474) al virus rugoso del tomate (ToBRFV). Dos muestras de ARN procedentes de Alemania (P12-3G, P12-3H) fueron sometidas a secuenciación, con un 99,6 \% identidad; las identidades de secuencia para los aislamientos de Jordania e Israel estuvieron en el mismo rango (99,7-99,8 \%) que apunta a un origen común (Menzel et al., 2019).

En Italia, en octubre del año 2018, en invernaderos de la provincia de Ragusa en Sicilia se observaron síntomas de virosis en cuatro invernaderos diferentes con producción de tomate rojo. Los síntomas eran mosaicos, deformación y necrosis en hojas jóvenes, y decoloración y deformaciones en frutos jóvenes. Las muestras se analizaron mediante RT-PCR, utilizando cebadores específicos para diferentes virus que causan síntomas similares en las plantas de tomate. El estudio logró identificar a ToBRFV como agente causal de la enfermedad. 
Las secuencias obtenidas mostraron una identidad $>99 \%$ con aislados de ToBRFV Tom1-Jo (número de acceso KT383474) y ToBRFV-IL (número de acceso KX619418). Para esta región se encontró una secuencia depositada en el GenBank con número de acceso MK313803 (Panno et al., 2019).

En Turquía, en enero del año 2019, plantas de tomate producidas en invernadero en la región mediterránea, presentaron síntomas en hojas como mosaicos cloróticos, moteados, rugosidad, enrollamiento, manchas necróticas en el pedúnculo, cálices y pecíolos; los cuales se asociaron a varios virus que afectan el tomate (Fidan et al., 2019). Las muestras se analizaron por RT-PCR para detectar la presencia del virus del mosaico de pepino (CMV), virus del mosaico del tabaco (TMV), virus del mosaico del tomate (ToMV) y virus de la marchitez del tomate (TSWV). Posteriormente se emplearon los cebadores genéricos (F-3666 / R-4718) utilizados por Luria et al. (2017), para detectar la infección por tobamovirus por RT-PCR, se obtuvo un fragmento de $1052 \mathrm{pb}$ al ser secuenciado, reveló una identidad de la secuencia del 98,0-98,9\% con los aislados de virus rugoso del tomate de Alemania, Israel y Jordania (Fidan et al., 2019) (GenBank número de acceso MK888980).

En abril del año 2019, en invernaderos de tomate de Yucheng provincia de Shandong, China, se detectaron plantas con síntomas de rugosidad marrón en fruto y de mosaico leve en las hojas. La incidencia de plantas enfermas se estimó en alrededor del $50 \%$. Las muestras fueron recolectadas y analizadas para detectar infección por virus mediante Western blot, ELISA y RT-PCR; la secuenciación confirmó la presencia del virus de la fruta rugosa marrón del tomate (Yan et al., 2019).

En el sur de Inglaterra, en julio del año 2019, se reportó una muestra de hojas de tomate (cv. Piccolo) con una infección viral con síntomas de mosaico, por lo cual realizaron una inoculación con una cepa de mosaico de pepino (PepMV) como tratamiento de protección cruzada; sin embargo, los síntomas persistieron después de la inoculación. La muestra se analizó usando kits ELISA para detectar la presencia de PepMV, virus del mosaico del tabaco, virus rugoso del tomate (ToBRFV) y virus del mosaico del tomate (ToMV). La muestra dio positivo para ToBRFV y PepMV, pero negativo para virus del mosaico del tomate, el resultado de ToBRFV fue confirmado por RT-PCR convencional con el empleo de cebadores específicos ToBRFV-F (5-AATGTCCATGTTTGTTACGCC-3) y ToBRFV-R (5-CGAATGTGATTTAAAACTGTGAAT-3) (Alkowni et al., 2019) y con cebadores genéricos de tobamovirus 514 Tombamo-s1 / 515 Tobamo-as1 (Menzel et al., 2019). La secuenciación de ToBRFV (MN182533) tenía entre 99,7 y 99,9 \% de identidad con genomas de aislados de ToBRFV de Israel (KX619418.1), Jordania (KT383474.1), Alemania (MK133095.1, MK133093.1), México (MK319944.1) y Palestina (MK165457.1) (Skelton et al., 2019). En el Cuadro 2 se muestran los informes de la presencia del ToBRFV a partir de de su aparición en Israel y Jordania.

De forma general, desde la aparición de ToBRFV en Israel y Jordania, se ha reportado y confirmado su presencia en ocho países (Figura 3), donde la fuente de transmisión es principalmente por inoculación mecánica, semilla contaminada y contacto entre plantas, y recientemente, se aborda el papel de los abejorros como portadores de inóculo primario de ToBRFV que contribuye a la propagación de la enfermedad en los tomates, ya que estos pueden haber transmitido el virus transfiriendo savia cruda usando sus mandíbulas, o mecánicamente a través de sus cuerpos vibrantes (Levitzky et al., 2019).

\section{Aparición en México}

En México, en agosto del año 2018, se alertó sobre la posible presencia de ToBRFV con productores de jitomate y chile de la región de Yurécuaro y Tanhuato, Michoacán, quienes reportaron síntomas en frutos con coloración amarilla, manchas verdes, malformación de frutos, estriado verde, manchas irregulares color marrón, hojas con mosaicos y moteado amarillento. Las muestras colectadas se analizaron mediante RT-PCR y amplificaron un producto esperado de 1052 pb. Las secuencias obtenidas de las muestras M1 (MK273183), M2 (MK273184), M5 (MK273187) y M7 (MK273189) tuvieron $100 \%$ de identidad con las secuencias de las muestras identificadas en Israel (KX619418.1) 
Cuadro 2. Reportes del lugar, fecha, hospedero y método de detección de virus de la fruta rugosa marrón del tomate (ToBRFV).

Table 2. Reports of the place, date, host, and detection method of tomato brown rugose fruit virus (ToBRFV).

\begin{tabular}{|c|c|c|c|c|}
\hline Lugar & Fecha de reporte & Hospedero & Método de detección & Cita \\
\hline Ohad, Israel & Octubre 2014 & $\begin{array}{l}\text { S. lycopersicum } \\
\text { C. апnит }\end{array}$ & $\begin{array}{c}\text { ELISA, RT-PCR, test } \\
\text { plants, secuenciación del } \\
\text { genoma }\end{array}$ & Luria et al. (2017) \\
\hline Jordania & Abril 2015 & S. lycopersicum & $\begin{array}{l}\text { ELISA, RT-PCR, test plant, } \\
\text { secuenciación del genoma }\end{array}$ & Salem et al. (2016) \\
\hline Westphalia, Alemania & Julio 2018 & S. lycopersicum & $\begin{array}{c}\text { test plant, RT-PCR, } \\
\text { secuenciación del genoma }\end{array}$ & Menzel et al. (2019) \\
\hline Baja California, México & Julio 2018 & S. lycopersicum & RT-PCR & $\begin{array}{c}\text { Camacho-Beltrán et al. } \\
\text { (2019) }\end{array}$ \\
\hline $\begin{array}{l}\text { California, Estados } \\
\text { Unidos }\end{array}$ & Septiembre 2018 & S. lycopersicum & $\begin{array}{c}\text { ELISA, RT-PCR, } \\
\text { microscopio de electrones, } \\
\text { test plant, secuenciación } \\
\text { del genoma }\end{array}$ & $\begin{array}{c}\text { Chitambar (2018), Ling } \\
\text { et al. (2019) }\end{array}$ \\
\hline Michoacán, México & Septiembre 2018 & $\begin{array}{l}\text { S. lycopersicum } \\
\text { Capsicum } \mathrm{sp}\end{array}$ & $\begin{array}{c}\text { RT-PCR, TEM, } \\
\text { secuenciación del genoma }\end{array}$ & Cambrón et al. (2018) \\
\hline Sicilia, Italia & Octubre 2018 & S. lycopersicum & $\begin{array}{c}\text { RT-PCR, test plant, } \\
\text { secuenciación del genoma }\end{array}$ & Panno et al. (2019) \\
\hline Antalya, Turquía & Enero 2019 & S. lycopersicum & $\begin{array}{c}\text { RT-PCR, genome } \\
\text { sequencing, test pla }\end{array}$ & Fidan et al. (2019) \\
\hline Shandong, China & Abril 2019 & S. lycopersicum & $\begin{array}{l}\text { ELISA, RT-PCR, test plant, } \\
\text { secuenciación del genoma }\end{array}$ & Yan et al. (2019) \\
\hline Sur de Inglaterra & Julio 2019 & & & Skelton et al. (2019) \\
\hline
\end{tabular}

ELISA: ensayo inmunoabsorbente ligado a enzimas; RT-PCR: reacción en cadena de la polimerasa con transcriptasa inversa; TEM: microscopía electrónica de transmisión / ELISA: enzyme-linked immunosorbent assay; RT-PCR: Reverse transcription polymerase chain reaction; TEM: transmission electron microscopy.

y Jordania (KT383474.1), mientras que las muestras M3 (MK273185), M4 (MK273186), M6 (MK273188) y M8 (MK273190) mostraron 99 \% de identidad con las mismas secuencias (Cambrón-Crisantos et., al 2018).

\section{Método de detección y control}

Actualmente solo hay algunas opciones disponibles para la detección de virus rugoso del tomate (ToBRFV). Se pueden visualizar partículas de virus con microscopía electrónica, pero no se pueden diferenciar de otros tobamovirus; existen anticuerpos que están disponibles para pruebas serológicas, sin embargo, estos antisueros a menudo reaccionan de forma cruzada con otros tobamovirus (Dovas et al., 2004). Para la identificación universal de tobamovirus se han reportado oligonucleótidos, los cuales fueron diseñados tomando una matriz de alineamiento de regiones conservadas en los ORF1 que codifican la RdRP de 32 tobamovirus (Li et al., 2018); sin embargo, hasta el momento no hay reportes de oligonucleótidos específicos para la detección de ToBRFV, por lo que se desarrolló un método de detección específico que incluye el diseño de un par de oligonucleótidos específicos para la amplificación de una región codificante de la replicasa (RdRP) viral (ORF1) del ToBRFV por RT-PCR, considerando específicamente las regiones nucleotídicas de los motifs estructurales o catalíticos, así como la estandarización del método de detección. 


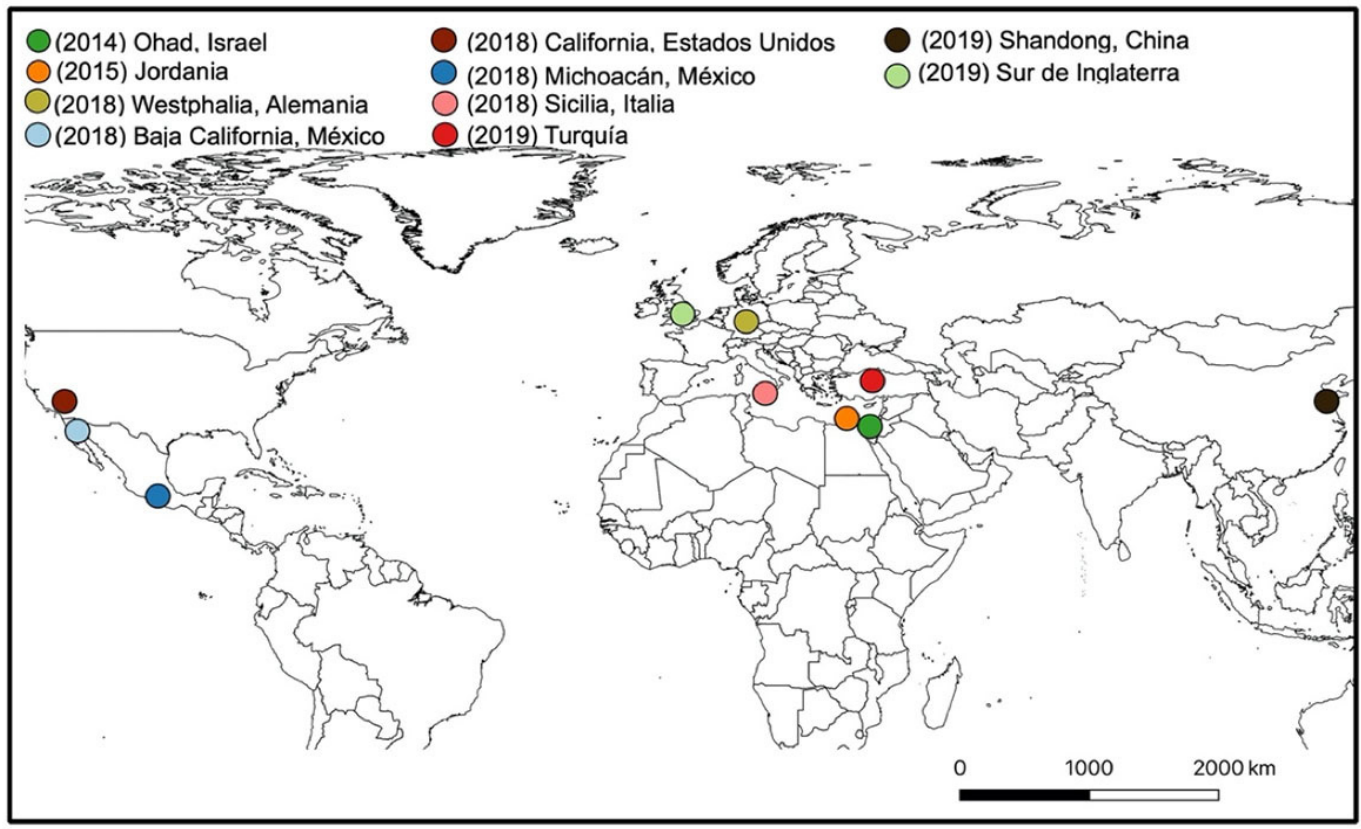

Figura 3. Países en los que se reportó la presencia del virus de la fruta rugosa marrón del tomate (ToBRFV). Periodo comprendido 2016 a 2019 (Elaborado con información de EPPO, 2019).

Figure 3. Countries in which the presence of tomato brown rugose virus (ToBRFV) was reported. Period from 2016 to 2019 (Elaborated with information from EPPO, 2019).

Para la identificación de ToBRFV en México, el Centro Nacional de Referencia Fitosanitaria y Rodríguez-Mendoza et al.(2019) diseñaron oligonucleótidos específicos (ToBRFV-FMX (25 nt)AACCAGAGTCTTCCTATACTCGGAA; ToBRFV-RMX (24 nt) CTCWCCATCTCTTAATAATCTCCT), para lo cual se consideró los genomas completos de las especies más representativas del género Tobamovirus, reportados por el Centro Nacional de Información Biotecnológica (NCBI, 2019), como: virus del mosaico del tabaco (TMV, Virgaviridae) (NC_001367.1, FR878069.1, HE818443.1 y V01408.1), virus del mosaico de tomate (ToMV, Virgaviridae) (NC_002692.1, KY967227.1, MF002490.1 y AF332868.1) y virus del mosaico moteado del tomate (ToMMV, Virgaviridae) (NC_022230.1, FX898034.1, KR824950.1 y KF477193.1); adicionalmente, se consideró los genomas de dos aislamientos de ToBRFV (Virgaviridae), uno israelí ToBRFV-IL (KX619418.1) y el otro jordano (KT383474.1). Con el programa BioEdit versión 7.0.5.3 (Hall, 1999) se hizo un alineamiento global de los genomas, utilizando el algoritmo Clustal $\mathrm{W}$ para generar la primera matriz e identificar regiones variables entre ellos.

Los protocolos de higiene son el paso más importante en la prevención de las infecciones por tobamovirus. Si se sospecha sobre una infección viral, el material vegetal debe ser destruido mediante incineración y no ser compostado ya que la partícula viral puede sobrevivir a este proceso. Actualmente, no hay información disponible sobre la descontaminación de sustratos de invernadero; por lo tanto, se recomienda no reutilizar sustratos. Existe un gran peligro de contaminación cruzada, si los mismos cultivos o huéspedes alternos a ToBRFV se cultivan después. El espacio del piso, cajas, contenedores, herramientas y utensilios deben desinfectarse con productos que tengan efecto sobre partículas virales (Richter et al., 2019). Para ello, se puede emplear hipoclorito de sodio (NaOCl) al $5 \%$, peroximonosulfato de potasio al $20 \%$, cloruro de sodio al $1,5 \%$ y cloruro de benzalconio al 0,1 \% (Li et al., 2015). 


\section{Conclusión}

Actualmente existe el reporte de presencia y distribución conocida de ToBRFV en México, Estados Unidos, China, Alemania, Turquía, Reino Unido e Italia. Las técnicas de diagnóstico empleadas utilizan oligonucleótidos específicos desarrollados a partir de los aislados de Israel y Jordania. Los oligonucleótidos diseñados permiten identificar de manera específica la presencia de ToBRFV en material vegetal, aportando así una metodología para la detección oportuna, en menor tiempo y con mayor especificidad, en comparación con el uso de oligonucleótidos generales para el género Tobamovirus, sin generar falsos positivos con otros virus.

Las medidas de bioseguridad implementadas en las unidades de producción son el paso más importante para la prevención y control del virus rugoso del tomate, ya que la falta de protocolos de higiene son un factor determinante en su dispersión. Estas medidas de bioseguridad son: utilizar semillas certificadas, libres del virus rugoso del tomate (ToBRFV). Para México el diagnóstico se debe realizar en el Centro Nacional de Referencia Fitosanitaria o laboratorios aprobados con protocolo transferido, destrucción de todas las plantas que presenten cualquier signo y/o síntoma asociado con la virosis, limpieza estricta dentro y fuera del invernadero y restricción de acceso al personal ajeno a las actividades en invernadero.

\section{Literatura citada}

Adams, M.J., J.F. Antoniw, and J. Kreuze. 2009. Virgaviridae: a new family of rod-shaped plant viruses. Arch. Virol. 154:19671972. doi:10.1007/s00705-009-0506-6

Alkowni, R., O. Alabdallah, and Z. Fadda. 2019. Molecular identification of tomato brown rugose fruit virus in tomato in Palestine. J. Plant Pathol. 101:719-723. doi:10.1007/s42161-019-00240-7

Camacho-Beltrán, E., A. Pérez-Villarreal, N.E. Leyva-López, E.A. Rodríguez-Negrete, E.A. Ceniceros-Ojeda, and J. MéndezLozano. 2019. Occurrence of tomato brown rugose fruit virus infecting tomato crops in Mexico. Plant Dis. 103:14401440. doi:10.1094/PDIS-11-18-1974-PDN

Cambrón-Crisantos, J.M., J. Rodríguez-Mendoza, J.B. Valencia-Luna, S. Alcasio-Rangel, C.J. García-Ávila, J.A. López-Buenfil, and D.L. Ochoa-Martínez. 2018. First report of tomato brown rugose fruit virus (ToBRFV) in Michoacan, Mexico. Mex. J. Phytopathol. 37:185-192. doi:10.18781/R.MEX.FIT.1810-5

Chitambar, J. 2018. Tomato brown rugose fruit virus. California Department of Food and Agriculture, USA. https://blogs.cdfa. ca.gov/Section3162/?p=5843 (accessed Jul. 10, 2019).

Christie, R., and J. Edwardson. 1994. Light and electron microscopy of plant virus inclusions. Monograph 9 (rev.). University of Florida, FL, USA.

Dawson, W.O. 1992. Tobamovirus-plant interactions. Virology 186:359-367. doi:10.1016/0042-6822(92)90001-6

Dombrovsky A, and E. Smith. 2017. Seed transmission of tobamoviruses: Aspects of global disease distribution. In: J.G. Jimenez-Lopez, editor, Advances in seed biology. InTechOpen, Rijeka, HRV. p. 233-260. doi:10.5772/intechopen.70244

Dovas, C.I., K. Efthimiou, and N.I. Katis. 2004. Generic detection and differentiation of tobamoviruses by a spot nested RTPCR-RFLP using dI-containing primers along with homologous dG-containing primers. J. Virol. Methods 117:137-144. doi:10.1016/j.jviromet.2004.01.004

EPPO (European and Mediterranean Plant Protection Organization). 2019. Tomato brown rugose fruit virus (ToBRFV): Distribution. EPPO global database. https://gd.eppo.int/taxon/TOBRFV/distribution (accessed Aug. 12, 2019).

Fidan, H., P. Sarikaya, and O. Calis. 2019. First report of tomato brown rugose fruit virus on tomato in Turkey. New Dis. Rep. 39:18. doi:10.5197/j.2044-0588.2019.039.018 
García, J.U., y D.A. Bocanegra. 2018. Análisis de riesgo para el tomato brown rugose fruit virus en México. SENASICA. MEX. http://sinavef.senasica.gob.mx/Eventos/Content/Multimedia/Analisis\%20de\%20Riesgo\%20para\%20el\%20ToBRFV.pdf (consultado 12 ago. 2019).

Hall, T.A. 1999. BioEdit: A user-friendly biological sequence alignment editor and analysis program for Windows 95/98/ NT. Nucleic Acid Symp. Ser. 41:95-98.doi:10.14601/Phytopathol_Mediterr-14998u1.29

Hanssen, I.M., R. Mumford, D.R. Blystad, I. Cortez, B. Hasiów-Jaroszewska, D. Hristova, and M. Ravnikar. 2010. Seed transmission of pepino mosaic virus in tomato. Eur. J. Plant Pathol. 126:145. doi:10.1007/s10658-009-9528-x

Levitzky, N., E. Smith, O. Lachman, N. Luria, Y. Mizrahi, H. Bakelman, N. Sela, O. Laskar, E. Milrot, and A. Dombrovsky. 2019. The bumblebee Bombus terrestris carries a primary inoculum of tomato brown rugose fruit virus contributing to disease spread in tomatoes. PLoS One 14(1):e0210871. doi:10.1371/journal.pone.0210871

Li, R., B. Gurel, Z. Abdo, A. Miller, and S. Ling. 2015. Evaluation of disinfectants to prevent mechanical transmission of viruses and a viroid in greenhouse tomato production. Virol J. 12:5 doi:10.1186/s12985-014-0237-5

Li, Y., G. Tan, P. Lan, A. Zhang, Y. Liu Y, R. Li, and F. Li. 2018. Detec-tion of tobamoviruses by RT-PCR using a novel pair of degenerate primers. J. Virol. Methods 259:122-128. doi:10.1016/j.jviromet.2018.06.012

Ling, K.S., T. Tian, S. Gurung, R. Salati, and A. Gilliard. 2019. First report of tomato brown rugose fruit virus infecting greenhouse tomato in the United States. Plant Dis. 103:1439. doi:10.1094/PDIS-11-18-1959-PDN

Luria, N., E. Smith, V. Reingold, I. Bekelman, M. Lapidot, I. Levin, N. Elad, Y. Tam, N. Sela, A. Abu-Ras, N. Ezra, A. Haberman, L. Yitzhak, and O. Lachman, and A. Dombrovsky. 2017. A new Israeli tobamovirus isolate infects tomato plants harboring Tm-22 resistance genes. PLoS ONE 12:e0170429. doi:10.1371/journal.pone.0170429

Menzel, W., D. Knierim, S. Winter, J. Hamacher, and M. Heupel. 2019. First report of tomato brown rugose fruit virus infecting tomato in Germany. New Dis. Rep. 39:1. doi:10.5197/j.2044-0588.2019.039.001

NCBI. 2019. Database resources of the national center for biotechnology information. Nucleic Acids Res. 45:(Database issue):D12-D17. doi:10.1093/nar/gkw1071

Panno, S., A.G. Caruso, and S. Davino. 2019. First report of tomato brown rugose fruit virus on tomato crops in Italy. Plant Dis. 103:1443-1443. doi:10.1094/PDIS-12-18-2254-PDN

Richter, E., M. Leucker, M. Heupel, C. Büttner, und Ziebell. 2019. Viren in Gemüse bekämpfen: Vorbeugen ist besser als Vernichten. Gemüse: das Magazin für den professionellen Gemüsebau 55(3):18-21.

Rodríguez-Mendoza, J., C.J. García-Ávila, J.A. López-Buenfil, K. Araujo-Ruiz, A. Quezada-Salinas, and J.M. CambrónCrisantos. 2019. Identification of Tomato brown rugose fruit virus by RT-PCR from a coding region of replicase (RdRP). Rev. Mex. Fitopatol. 2019:345-356. doi:10.18781/R.MEX.FIT.1902-6

Salem, N., A. Mansour, M. Ciuffo, BW. Falk, and M. Turina. 2016. A new tobamovirus infecting tomato crops in Jordan. Arch. Virol. 161:503-506. doi:10.1007/s00705-015-2677-7

Skelton A, A. Buxton-Kirk, R. Ward, V. Harju, L. Frew, A. Fowkes, M. Long, A. Negus, S. Forde, IP. Adams, H. Pufal, S. Mc Greig, R. Weekes, and A. Fox. 2019. First report of tomato brown rugose fruit virus in tomato in the United Kingdom. New Dis. Rep. 40:12. doi:10.5197/j.2044-0588.2019.040.012

Van-Regenmortel, M.H.V. (ed.). 2000. Virus taxonomy: classification and nomenclature of viruses. Seventh report of the International Committee on Taxonomy of Viruses. International Committee on Taxonomy of Viruses. Academic Press, MA, USA.

Yan, Z.Y., H.Y. Ma, S.L. Han, C. Geng, Y.P. Tian, and X.D. Li. 2019. First report of tomato brown rugose fruit virus infecting tomato in China. Plant Dis. 103:2973-2973. doi:10.1094/PDIS-05-19-1045-PDN 